\title{
The Nature of Startup Development: Concepts, Theories, Trends, Conditions
}

\author{
Alla Kasych ${ }^{1}$, Aliaksandr Amelyaniuk ${ }^{2}$ \\ ${ }^{1}$ Kyiv National University of Technologies and Design, Kyiv, Ukraine \\ ${ }^{2}$ Brest State Technical University, Brest, Belarus
}

\begin{abstract}
The article investigates topical issues of startup development through the prism of the possibility of implementing the entrepreneurial activity. The basis of the study was the generalization of the development of the theory of startups through the prism of the theory of management, entrepreneurship, innovation, and theory of organizations. Understanding the nature of startups allows us to determine the conditions for intensifying their development. The article also systematized the existing methods of analyzing the effectiveness of startups. The main trends in the development of the startup movement in different regions and countries of the world were identified based on the analysis of the international experience of startups. The article also researches the interaction between startups and corporations in the context of advantages for both parties. It is emphasized that an essential condition for the development of startups is the formation of the entrepreneurship ecosystem.
\end{abstract}

Keywords: startup, business, entrepreneurial activity, indicators, complex process

\section{Introduction}

In the XIX-XX centuries, the leading role in the economic development held by the material production sectors, in particular oil, metallurgy, machine building, and others, but in current conditions, the most dynamically growing business is formed based on knowledge and innovations. A convenient way to start a business for those who want to implement their creative ideas and set up a successful and fast-growing enterprise is to create a startup. Unexpected ideas, which in most cases are very difficult to develop due to lack of resources, can not only be transformed into a real growing business through seed financing but also reach the level of global players, especially in the sector of information technology, pharmacy and others. 
On the other hand, existing companies, lacking innovation, actively support the startups. Startups as an element of market infrastructure play an increasing role. Large firms are, on average, more productive than smaller ones, especially in the manufacturing sector, but some small firms often superior to larger companies by taking competitive advantage in high-brand or highly intelligent niche, with intellectual property activities. An essential factor in the development of startups in modern conditions is the rapid development of information and communication technologies, digitalization of the economy. Both universities and public authorities pay attention to stimulating the development of startups in modern conditions. The search for ideas and the creation of conditions for their implementation are the key phases of the innovation process, which has become a driver of economic development. Every entrepreneur in the initial stages aims to make a profit, but only 1 in 12 succeed in doing so.

That is why the processes of developing startups from the standpoint of creating conditions and transforming into real enterprises in the context of the formation of practical recommendations for initiation need to be studied. Various aspects of startup management are presented in the works of Mrykhin (2015), Lalu (2017), Til (2015), Ivashova (2013), Blank (2013), Ris (2012).

Thus, Watson and Hogarth-Scott (1998) are studied the creation and the survival of small and micro enterprises, as well as the role of public authorities to support their development. The focus is also on the viability and the importance of startups to ensure the development of developing countries, emphasize Okrah, Nepp, and Agbozo (2018). Researchers note that the critical conditions for activating the startup movement are the internal market openness and government policies that highly influence the financing of startups.

Cheah, Ho, and Lim (2016), Zilgalvis (2014), Dolfsma and Seo (2013), Minniti (2008) reveal differences in the processes of startups formation in different regions of the world. The content of the public policy of promoting entrepreneurial activity in the country and creating systemic conditions for the development of startups are studied by Minniti (2008), Patanakul and Pinto (2014).

\section{Methods and Data}

The purpose of the article is to investigate the theoretical, organizational, and methodological issues of activating the processes of startups creating, the practice of managing them, and to justify the measures necessary to enhance entrepreneurship, which is essential for any country.

For this goal, the following main tasks would be considered:

- to generalize existing approaches to understanding the nature and features of startups;

- to explore holistic models of startups and stages of their formation;

- to establish the critical trends of startups' development in different countries; 
- to substantiate the fundamental conditions and measures to intensify the processes of creating startups.

Research methods were used: quantitative and qualitative, analytical and comparative, statistical information processing, analysis and synthesis, economic and mathematical modeling, etc.

Scientific novelty and practical significance lie in the systematization of methodological approaches to the analysis of the development of startups and the development of proposals for activating the startup movement.

For understanding the nature of the startup movement, it is advisable to research at the macro level, at the regional level and, directly, individual startups.

The main indicators used to study the development processes of startups are: the number of startups in terms of regions of the world, countries, per capita; investments in startups in various forms; the share of the population covered by entrepreneurial activity and involved in the creation of startups.

International organizations use the following indicators:

Entrepreneurial employee activity (EEA) it is a share of the population between the ages of 18 ad 64 that is now actively involved and plays a leading role in developing an idea or preparing and implementing a new activity for its employers, such as developing or launching new goods or services or creating a new business unit or subsidiary (Europe's Hidden Entrepreneurs Entrepreneurial Employee, 2016).

The indicator of the total early-stage entrepreneurial activity (TEA) of the economy is defined as the level of prevalence of people of working age who are actively involved in business startups, or on the pre-birth phase of the firm (startup entrepreneurs), or the phase that covers 42 months after the birth of the firm (owners or managers of new firms). That is to say; it is the percentage of the population aged 18-64 who is either a nascent entrepreneur or a new business owner-manager.

The indicator can be divided into two parts: TEA based on an opportunity (easiest to explain as entrepreneurs who could find a job but decided to do business on their own) and TEA based on need (easiest to explain as entrepreneurs who could not find a job and started their business to survive).

In the US, calculate the Kaufman Startup Activity Index (The Kauffman Index of Startup, 2016), which integrates and bases on three components: the fraction of new entrepreneurs in the economy (calculated as the percentage of adults becoming entrepreneurs this month), the possibility of new entrepreneurs (calculated as the percentage of new entrepreneurs), motivated by "opportunity" rather than "necessity" the density of startups in the regions (the ratio of the number of new employers based on the number of economic entities).

It is far from being a full list of metrics used for startups. All indicators can be divided into two groups: indicators that characterize the results of startups and indicators that reflect 
the conditions and motives for doing business. Some of the presented indicators will be used in the process of further analysis.

\section{Results}

The concept of "startup" has recently become widespread and influential. Creating startups is relatively new and requires a systematic understanding, in the context of activation and, therefore, in the theoretical, methodological, and applied way.

The most common concept of a startup is considered to be the definition formulated by the successful American startupper Stephen Blank, namely: "a startup is a temporary structure aimed at finding and implementing a scalable business idea" (Blank, 2013).

In general, it is a term used to describe a business that works to create products or provide services to solve modern problems or meet current requirements, because the solution is not clear and success is not guaranteed (Heyets, 2015). A startup is a process for implementing an utterly young project with minimal investment in a short space of time. This form of business's main characteristics are based on the very definition: start - as the beginning, "up" - as a rapid rise, growth. Scientific approaches to understanding the concept of "startup" are presented in table 1.

Tab. 1: The essence of the concept «startup»

\begin{tabular}{|l|l|}
\hline \multicolumn{1}{|c|}{ Author } & \multicolumn{1}{c|}{ Definition } \\
\hline Blank, 2013 & $\begin{array}{l}\text { Startup (from the English. Start-up - start, run) - is a } \\
\text { temporary organization created to find a repetitive, scalable, } \\
\text { and sustainable business model. }\end{array}$ \\
\hline $\begin{array}{l}\text { Kashirin and } \\
\text { Semenov, 2008 }\end{array}$ & $\begin{array}{l}\text { A startup is a new company at the initial stage of its } \\
\text { development, which is created to implement a promising idea } \\
\text { to receive high profit. }\end{array}$ \\
\hline Greham, 2012 & $\begin{array}{l}\text { A startup is a growth. } \\
\text { products or services in conditions of extreme uncertainty. }\end{array}$ \\
\hline Mrykhina, 2015 2012 & $\begin{array}{l}\text { Startup - the market entry process of a newly created } \\
\text { enterprise with an innovative project, usually in the short term } \\
\text { and with minimal investment. }\end{array}$ \\
\hline $\begin{array}{l}\text { Puropean } \\
\text { Startups, 2018 }\end{array}$ & $\begin{array}{l}\text { A startup is a newly created company (sometimes not even a } \\
\text { legal entity), which is on the development stage and builds its } \\
\text { business either based on new innovative ideas or newly } \\
\text { invented technologies. } \\
\text { innovative, technological product with high and rapid growth. }\end{array}$ \\
\hline
\end{tabular}

Source: Authors. 
In general, this term is used to describe a business that works to create products or provide services to solve modern problems or meet current requirements, because the solution is not clear, and success is not guaranteed (Mansfield, 2018).

The presented definitions testify to this concept's capacity and scope: from the appearance of the idea to the enterprise at the initial stages. Also, studying the nature of startups makes it advisable to focus on comparing the concepts of "startup" and "entrepreneur." Thus, for a startup in the first place - attracting investment to realize his idea, he spends much effort to realize dreams and ideas, and his main priority is not business, but the commercialization of ideas. Entrepreneur, at the same time, is most often engaged in traditional business, can run startups, and the main priority is business.

Startups should be explored from positions of organizational theory, management theory, and entrepreneurship. In terms of the theory of organizations, it is essential to study the issue of the rapid transformation of an idea into a growing enterprise, management theory is enriched by the study of modern management methods of small teams, and business theory focuses on studying the nature of ideas and entrepreneurial initiatives. Startups also play an important role in innovation theory as part of the innovation infrastructure.

Startup as the original form of enterprise existence is an important area of study of the organization's theory. Given the characteristics of this form of starting a business to understand the mechanisms of "start," it is advisable to take into account the stages of the life cycle, which is proposed in the paper (The Kauffman Index of Startup Activity, 2016).

The process of transforming startups into enterprises with the specification of stages, their content, forms, and time horizons are presented in figure 1.

Figure 1: Stages of transformation of startups into enterprises

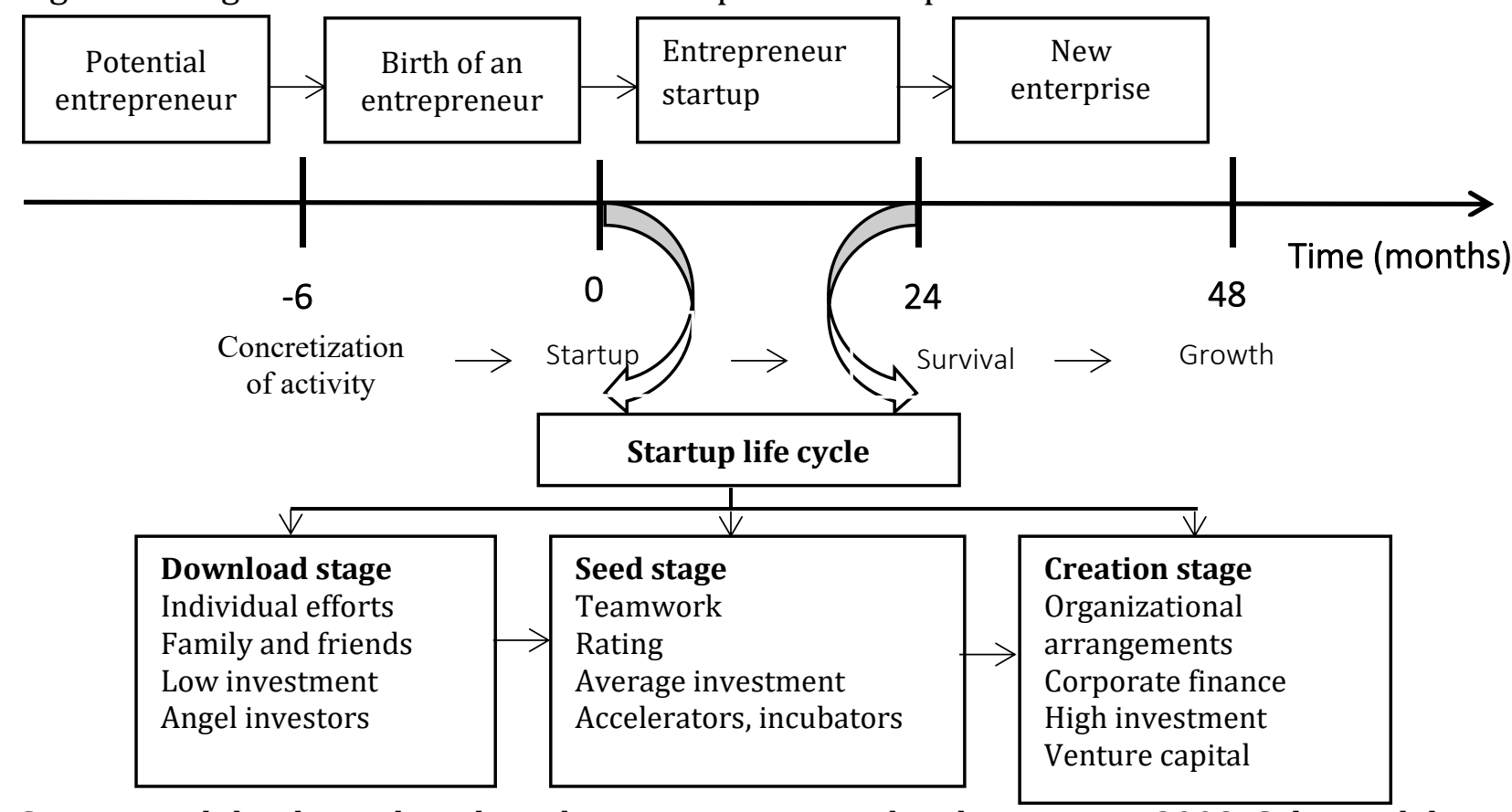

Source: Built by the authors based on Bosma, Meijaard and van Popta, 2002; Salamzadeh, and Kesim, 2015; Kasych and Dzhura, 2019. 
At the loading stage, efforts are made to turn the idea into a profitable business by positioning the idea, justifying the feasibility of the product or service, the implementation of "sowing" financing. In the second stage, a team is created, and average investments are provided, in general, an attempt is made to enter the market. Stage of organizational separation of ideas through the creation of a real enterprise - it is at this stage that entrepreneurship ceases, as the established enterprise proceeds to production. This process can take up to two years.

Since a startup is a rather complex process in terms of initiation and traditional management models and methods do not work, the main focus in management theory should be on managing the factors of startup development and finding management tools in conditions of high uncertainty. The most common in such conditions are (Voloshin, 2017):

The Blanc-Dorf model (the concept of consumer development) does not involve closing the startup after failure, but finding new ways to implement it through consumer orientation and interaction with him.

Osterwald model (9-block model of startup monitoring), include key partners, key activities, benefits and offers, customer relations, user segments, essential resources, supply channels, cost structure, and revenue sources, in order to find weaknesses and find competitors benefits of the idea.

Esh Maurya's (lean canvas) model focuses on eliminating the causes of losses by involving the whole team in the process.

Another critical area of research of startups within the management theory is the search for the optimal business model in startup projects (Lalu, 2017). Bringing an idea to market requires knowledge of management, respectively, scientists are exploring the most appropriate methods to promote a startup project.

Innovation theory systematically investigates, among other things, the development of innovation infrastructure, an essential element of which is a startup. The developed innovation infrastructure ensures the full functioning of the chain "idea generation development of innovative products - development of innovative capabilities of companies - production of innovative products - sales of innovative products." To innovation intensify through startups, infrastructure elements are needed that: first, will help finance startups (venture funds, seed funds, pilot centers for commercialization and technology transfer); secondly, they will provide organizational and technological conditions (technology parks, science towns, business incubators, clusters, centers for collective use of unique scientific equipment, etc.).

The theory of entrepreneurship focused on examining the conditions for individuals' initiative-taking activities, able to concentrate efforts not only on finding and justifying the idea but then on attempting to implement it independently. That is why in the theory of entrepreneurship startups are studied in the context of studying the processes of initiation of creative and creative activity of individuals and market testing of the formed 
ideas. For this, a startup culture must be formed in the country, which would ensure the spread of the desire to start a business to implement their own ideas. However, it should be taken into account that in the conditions of developed market systems the accents of corporate culture have changed: from the ideas of "success through development" there has been a transition to the idea of "success through sales" (meaning the sale of successful businesses).

In the context of startups' nature study and determining the characteristics of this form of business organization, it is worthwhile to compare with another form of innovation, in particular with small businesses. They have some standard features: they are usually created by startup entrepreneurs and are small in scale. The startup team consists of 210 people, and the average number of employees in small businesses up to 50 people. Startups, as well as small businesses, operate at risk, have a volatile market position, need investment for successful development. Despite the common features, there are also some differences regarding product innovation, the scope of activity, successful development trajectory, the scale of activity, infrastructure, investment mechanisms, etc. Startups arise for the implementation of new innovative products, while small businesses focus on new or existing business models.

Thus, the main characteristics of startups are the presence of a creative idea, entrepreneurial initiative, short implementation period of the idea, the minimum amount of investment, continuation in the form of a new enterprise.

For the effective management of the startups' development process, it should be clearly understood not only their main stages of development but also measures to ensure the introduction of new ideas through the startup into the market and production through powerful enterprises (figure 2). 
Figure 2: Key stages of functioning of old-timers

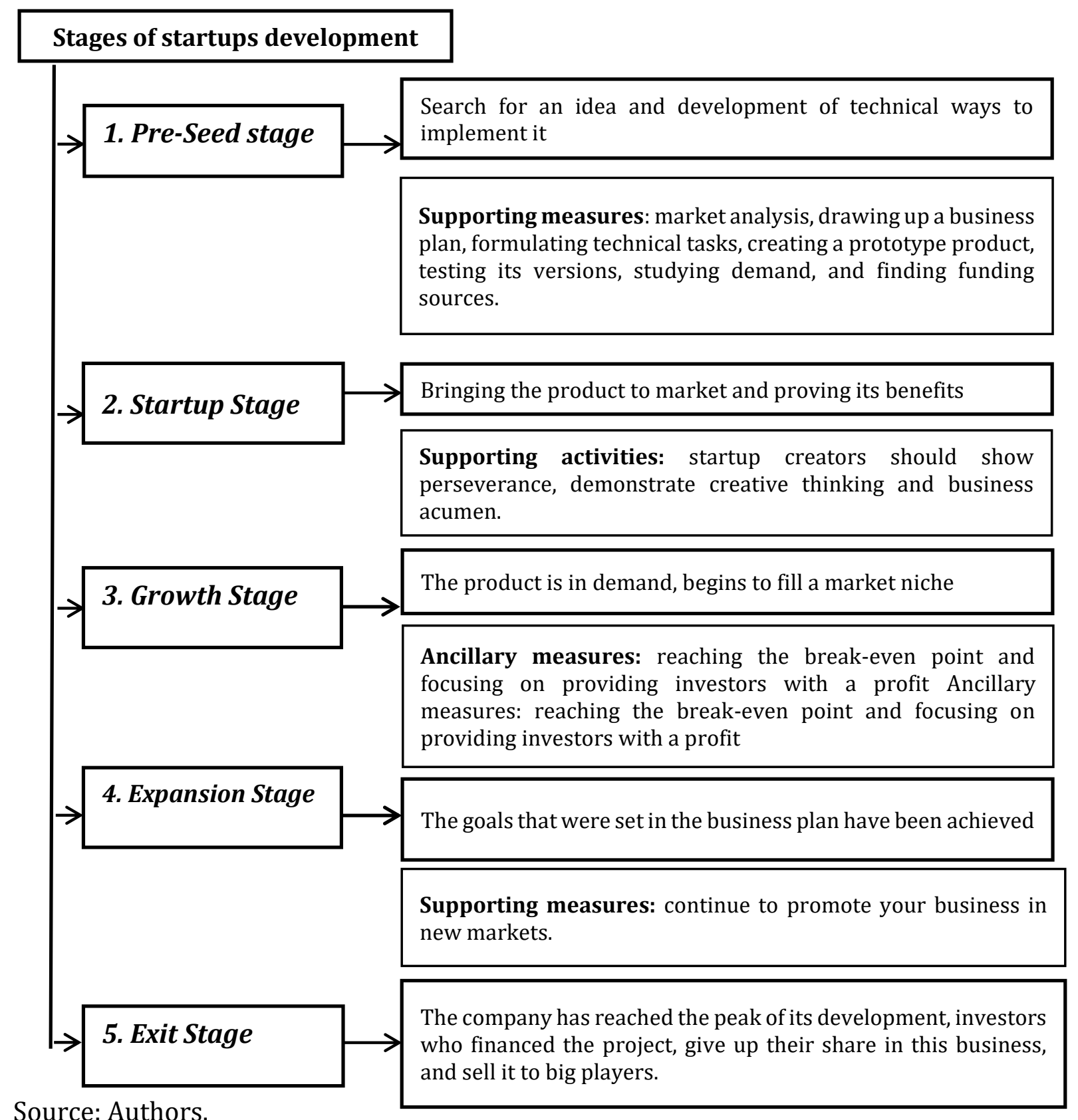

Source: Authors.

Indeed, the role of startups in modern conditions is to bring innovation in the form of participants' ideas to the market and bring it to the user, able to ensure the commercialization of them systematically. A startup is a temporary infrastructure element that seeks a scalable, cost-effective business model that can deliver reproduction. The main limitations that destroy startups are the lack of demand and a large amount of startup investment. That is, startup combines the characteristics that allow today to operate in the complex conditions of today's market. The convergence of interests of startup ensures the development of this form of innovation and entrepreneurship.

The authors of the idea and the investors are equally interested in the financial success of the startup. Each of them, in case of victory, will receive the benefit. The 
investor always risks more, but if we talk about profit, it will also be higher than the profit of the startup. It is the investor, who receives most profits because he provides financial support and risks in case of failure. The developer has an interest in this business: he invests his opportunities in the startup - seeks to implement their ideas, gain success and recognition, does his favorite thing, and hopes to be rewarded for their efforts. The investor's interest is to increase capital. It happens in two ways, through an investment in a growing business or selling your share at a higher price (also could keep it and receive passive income).

Thus, startups are an effective form of strengthening the innovative business activity and entrepreneurship of creative people. Given the slowdown of scientific progress dynamics, the role of startups is growing and therefore requires more systematic research to ensure targeted management of these processes.

The startups' development, based on their role in economic development in current conditions, is given great attention around the world and is monitored accordingly. Next, we should focus on the study of international experience and identify the main trends in startups development:

1. In recent years, the world is experiencing a startups revolution; the amount of capital invested in startups through venture funds reached the largest in ten years the value of 140 billion U.S. dollars in 2017. The total value of the created global startup economy for 2016-2018 increased compared to the 2015-2017 period by $20.6 \%$ and reached 2.8 trillion U.S. dollars (Graham, 2012).

2. In the process of startups establishing, there are some regional differences, even though there is a total increase in their number in the world, as well as improving the general conditions for development (Table 2, figure 3). 
Tab. 2. Indicator of the general initial stage of entrepreneurial activity (TEA)

\begin{tabular}{|l|c|c|c|c|c|c|c|c|c|}
\hline Countries & 2005 & 2010 & 2013 & 2014 & 2015 & 2016 & 2017 & 2018 & 2019 \\
\hline World & $\mathbf{6 . 2}$ & $\mathbf{7 . 8}$ & $\mathbf{1 0 . 7}$ & $\mathbf{1 0 . 9}$ & $\mathbf{1 0 . 2}$ & $\mathbf{1 0 . 2}$ & $\mathbf{1 0 . 3}$ & $\mathbf{1 0 . 2}$ & $\mathbf{1 0 . 3}$ \\
\hline Brazil & 11.3 & 17.5 & 17.3 & 17.2 & 20.9 & 19.6 & 20.3 & 18.5 & 23.3 \\
\hline Mexico & 5.9 & 10.5 & 14.8 & 18.9 & 21.0 & 9.6 & 14.1 & 13.6 & 13.0 \\
\hline USA & 12.4 & 7.6 & 12.7 & 13.8 & 11.9 & 12.6 & 13.6 & 15.4 & 17.4 \\
\hline Canada & 9.3 & 8.8 & 12.1 & 13.0 & 14.7 & 16.7 & 18.8 & 18.5 & 18.2 \\
\hline $\begin{array}{l}\text { Great } \\
\text { Britain }\end{array}$ & 6.2 & 6.4 & 7.1 & 10.7 & 6.9 & 8.8 & 8.4 & 8.2 & 9.3 \\
\hline Germany & 5.1 & 4.2 & 4.9 & 5.2 & 4.7 & 4.6 & 5.3 & 5.0 & 7.6 \\
\hline France & 5.4 & 5.8 & 4.8 & 5.3 & 5.3 & 5.3 & 3.9 & 4.2 & 4.6 \\
\hline Estonia & m.d. & m.d. & 13.1 & 9.4 & 13.1 & 16.2 & 19.4 & 18.9 & 18.6 \\
\hline Poland & 8.8 & 8.9 & 9.2 & 9.2 & 9.2 & 10.7 & 8.9 & 7.8 & 5.4 \\
\hline Japan & 2.2 & 3.3 & 3.7 & 3.8 & 4.1 & 4.2 & 4.7 & 5.1 & 5.4 \\
\hline China & 13.7 & 14.4 & 14.0 & 15.5 & 12.8 & 10.3 & 10.2 & 9.8 & 8.7 \\
\hline
\end{tabular}

Source: Compiled by the authors according to The Startup Europe Ecosystem (2018); Global Startup Ecosystem Report (2019).

Figure 3: Indicator of the general initial stage of entrepreneurial activity (TEA)

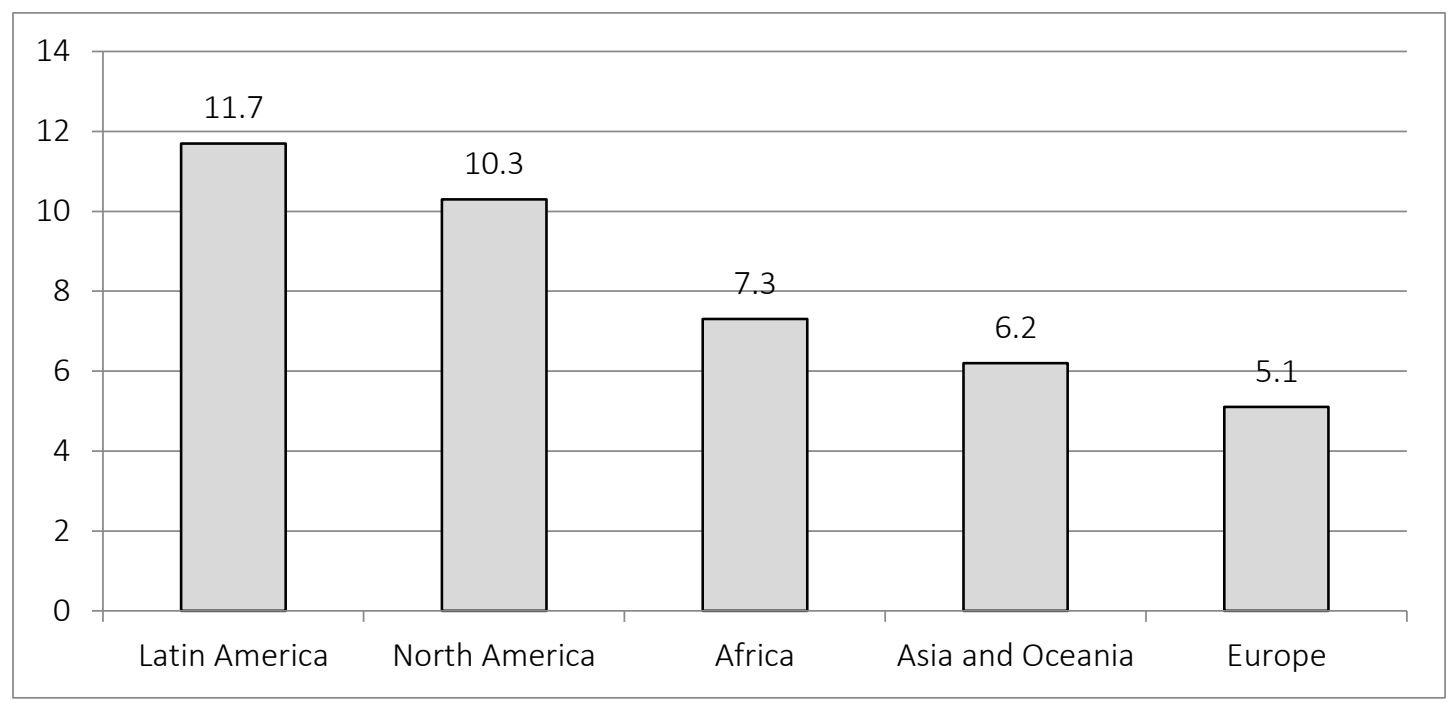

Source: Compiled by the authors according to The Startup Europe Ecosystem (2018).

Although most valuable startups are located in the United States or China, Latin America and the Caribbean are currently the world's most active region for startups. About a third of Ecuador's population is involved in starting a business, compared to $13 \%$ in the United States. Lebanon, Vietnam, and Estonia also have high levels of new business. The Latin American and Caribbean region had the highest level of startups worldwide in 2017: about 11.7 percent of the working-age population is involved in new entrepreneurial activities. Even North America has a lower rate. The lowest level of entrepreneurial 
activity in Europe is entirely indicative, which allows us to emphasize the potential problem of the region in terms of innovation and sustainability of economic development. In Europe, only post-socialist countries show an increase in entrepreneurial activity, and in developed EU countries, this figure is at the level of $4 \%$ - France to $8 \%$ in the UK. It should be noted that it is the United Kingdom that has taken unprecedented steps in recent years to intensify entrepreneurial initiatives.

3. The efficiency of entrepreneurial activity in terms of the number of successful startups differs significantly in different countries. The indicator of the relative level of population entrepreneurial activity is the total number of startups that are created (Table 3).

Tab. 3: Indicators that characterize the development of startups in different countries in 2017

\begin{tabular}{|l|c|c|c|c|c|}
\hline Countries & $\begin{array}{c}\text { Number } \\
\text { of } \\
\text { startups }\end{array}$ & TEA & $\begin{array}{c}\text { Good } \\
\text { career } \\
\text { choices }\end{array}$ & $\begin{array}{c}\text { Entrepreneurial } \\
\text { intentions }\end{array}$ & $\begin{array}{c}\text { Funding } \\
\text { problems }\end{array}$ \\
\hline USA & 46377 & 13.6 & 63.1 & 14.5 & 5.2 \\
\hline India & 6028 & 9.3 & 53.0 & 10.3 & 37.9 \\
\hline $\begin{array}{l}\text { Great } \\
\text { Britain }\end{array}$ & 4871 & 8.4 & 55.6 & 7.3 & 8.4 \\
\hline Canada & 2454 & 18.8 & 65.6 & 14.1 & 11.9 \\
\hline Indonesia & 2012 & 7.8 & 70.0 & 28.1 & 39.5 \\
\hline Germany & 1965 & 5.3 & 51.3 & 7.2 & 5.7 \\
\hline France & 1383 & 3.9 & 59.1 & 17.6 & 16.6 \\
\hline Brazil & 1069 & 20.3 & m.d. & 15.3 & 17.8 \\
\hline China & 545 & 9.9 & 66.4 & 15.3 & 31.2 \\
\hline Ukraine & 238 & m.d. & m.d. & m.d. & m.d. \\
\hline Estonia & 157 & 19.4 & 54.2 & 18.1 & 10.7 \\
\hline Latvia & 70 & 14.2 & 57.5 & 17.3 & 9.3 \\
\hline Slovakia & 59 & 11.8 & 47.6 & 9.0 & 12.2 \\
\hline
\end{tabular}

Source: Compiled by the authors according to The Startup Europe Ecosystem (2018).

The undisputed leader in creating successful startups is the United States. Startups in this country have good conditions: infrastructure, interest from companies, significant financial opportunities. Thus, the total amount of venture capital invested in startup companies, at an early and late stage (also known as investment growth stage), in 2016 was $\$ 33$ billion compared to $\$ 41$ billion in the previous year.

Interesting in the context of results is the ratio in some countries of a relatively low level of the total initial stage of entrepreneurial activity (TEA) and the number of successful 
startups. Thus, a relatively low level of activity gives in India, Indonesia quite significant results. In some countries, such as Canada and Brazil, the basis for high productivity is to stimulate a high level of entrepreneurial activity.

Another important indicator of the effectiveness of startups is their profitability. However, only 40 percent of small businesses are profitable, and 30 percent are constantly losing money (Mittal, 2014). That is why, first of all, financial conditions are necessary for the intensification of entrepreneurship.

4. Development conditions of entrepreneurial activity differ significantly in different countries. The presented indicators (Table 3) and the identified trends testify that the studied processes are very complex; therefore, international analytical agencies are very carefully studying the development conditions of entrepreneurship in the early stages. Among the most important conditions: availability of entrepreneurial capital, government policy, support and government programs for entrepreneurship development, entrepreneurship education, opportunities for technology transfer, access to international markets and domestic regulations, available infrastructure (market, commercial, transport, other), cultural and social conditions, etc.

Here are the indicators that characterize the development conditions of startups and are presented in table 3.

Good career choices are the percentage of adults between the ages of 18 and 64 who believe that entrepreneurship is a good career choice.

Fear of failure - the percentage of the population aged 18 to 64, who perceive excellent opportunities to start a business, which indicates that the fear of failure prevents them from starting a business.

Entrepreneurial intentions - the percentage of the population aged 18 to 64 (persons involved in any stage of exclusion of entrepreneurial activity), who are hidden entrepreneurs and who intend to start a business within three years.

Yes, as shown in the table 3 in the vast majority of countries, the percentage of the population who perceive entrepreneurship as a good choice exceeds $50 \%$, which means that every second person can try themselves in this area under certain conditions. The indicator of entrepreneurial intentions for three years is much lower.

5. The issue of funding is the second after the initiative in importance in the implementation of startups. Eighty percent of failed businesses do so because of cash flow problems. Moreover, although startups, by definition, do not require significant financial resources, their absence can be an insurmountable obstacle. The vast majority of startup funds (82\%) are formed at the expense of the entrepreneur, family, and friends. Seventy-seven percent of small businesses rely on personal savings for their initial funds (Mittal, 2014).

6. The process of creating startups has specific age characteristics of entrepreneurs. Thus, 51 percent of small business owners are people aged 50-88, 33 percent - 35-49 years old, and only 16 percent to 35 years. 
The table 4 provides an overview of the ranking of industries by TEA indicator and by region.

Tab. 4: Ranking of industries by TEA indicator by region, 2017

\begin{tabular}{|c|c|c|c|c|c|c|c|c|c|c|}
\hline \multirow[t]{2}{*}{ Regions } & \multicolumn{10}{|c|}{ Branches } \\
\hline & 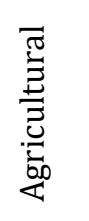 & $\stackrel{\infty}{\stackrel{\Xi}{\Xi}}$ & $\begin{array}{l}\vec{E} \\
\underline{\Xi} \\
\vec{E} \\
\Xi\end{array}$ & 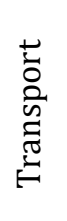 & 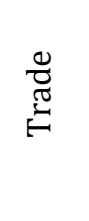 & $\underline{\varrho}$ & 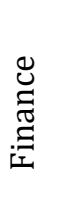 & 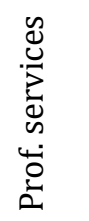 & 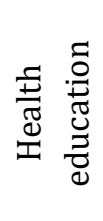 & $\begin{array}{l}\dot{\Xi} \\
\tilde{0}\end{array}$ \\
\hline $\begin{array}{l}\text { Latin } \\
\text { America }\end{array}$ & 2.6 & 3.7 & 9 & 3.4 & 55.7 & 2.8 & 1.1 & 4.1 & 12.2 & 5.4 \\
\hline $\begin{array}{l}\text { North } \\
\text { America }\end{array}$ & 4.2 & 4.9 & 6.2 & 2.2 & 21.6 & 8.5 & 7.6 & 16.1 & 17.1 & 11.6 \\
\hline Africa & 12.6 & 3.6 & 11.8 & 3 & 53.5 & 1 & 1.6 & 0.7 & 8.1 & 4.1 \\
\hline $\begin{array}{l}\text { Asia and } \\
\text { Oceania }\end{array}$ & 3.4 & 4.2 & 7.2 & 2.1 & 52.5 & 3.3 & 3.1 & 4.4 & 13.8 & 6 \\
\hline Europe & 7.1 & 6.6 & 8.3 & 2.8 & 27 & 5.5 & 3.9 & 11.6 & 17.6 & 9.6 \\
\hline
\end{tabular}

Source: Compiled by the authors according to Global Entrepreneurship Monitor (2017).

Thus, startups in agriculture and industry are most actively created in countries of Africa, due to the low technological development of most of them and the need to address the problems of food security. The largest in countries of North America and Europe is the share of startups in the information and communication technologies field and professional services. Startups in trade are more active (at more than 50) in Latin America, Africa, and Asia. Such important sectors of the economy as education and health care in all regions are characterized by the relatively similar activity of startup processes, with a predominance in Europe and North America. In general, on the global market in the conditions of global competition, the advantages are those who have an effective mechanism of innovation and have a developed infrastructure for the creation and implementation of innovations. When the innovation infrastructure is sufficiently developed, it increases the pace of economic development and increases the population welfare.

In the study of international experiences of the startup movement revitalization, we should focus on the United Kingdom's practice, which revolutionized after the crisis of 2009-2010 and now, except for the United States, has no similar conditions for starting and developing a business. Thus, in 2015, 608 thousand companies were founded in the UK, and 2016 - 660 thousand (Number of UK start-ups, 2017). Government initiatives included regulatory support for innovative high-tech industries, tax simplification, and reduction of corporate tax rates to boost investment directly in the early stages of the innovation process. As a result, in a few years, and especially in London, there has been a breakthrough in innovation and finance, and the main idea is gaining new momentum - 
"from local startups to international markets". The experience of the United Kingdom has also become famous for dissemination in other EU countries.

In recent years, policies to promote the startups' development have significantly intensified in the EU (The Startup Europe Ecosystem, 2018). The European Commission has launched the Startup Europe initiative, which aims to strengthen the European business ecosystem. It is determined that the EU policy should be aimed at the support three phases of entrepreneurship: buffering, support of ideas at the initial stage of entrepreneurial activity, a combination of startups with external entities in the ecosystem; implementation of measures aimed at accelerating the growth of promising enterprises. Both financial and non-financial support tools should be used. Among the financial instruments, the most important are: bank loans for "start" with the support of the government; co-financing funds and partnerships set up by banks and industrial enterprises; regional development funds; introduction of financial support programs for the unemployed; tax benefits for corporate and individual startup investors.

International experience shows that the development of startups is essential and needs systematic support at the national and regional levels. The startups' development in the country can and should become a mechanism that will increase the attractiveness of the investment climate, ensure the development of innovation and support for small and medium-sized businesses. The consequence of this will be an increase in the overall level of production and sustainability of the country's economy.

Based on the fact that the startup's life cycle's most important and complex phases are the idea initiation and financial support at the riskiest moment, the task of their development should be considered in this context. Among the primary fields where changes are needed are growing importance of universities, intensifying the interaction of startups and large corporations, creating favourable conditions for enterprise development in certain regions through the formation of clusters, and forming state policy to support startups.

1. The ideas' initiation largely depends on the formation of creative and creative thinking in young people, which determines the role of universities in these processes. Universities, with their experience, infrastructure, and significant investment in research, are a "fertile ground" for innovation that can be used potentially to create new products and services. Universities also have experience in protecting intellectual property rights, technology transfer, etc. Universities are the growth point of startups in developed countries, as they ensure not only the intellectual potential development of the younger generation, but also create infrastructural, informational and, to some extent, financial conditions.

It takes a lot of time and resources to bring ideas to the market because new technologies and products do not guarantee success. Successful technology transfer allows university research programs to be more influential and concretely improve the lives of our citizens while generating income that can support future research programs and provide returns or stakeholders such as inventors, research programs, and taxpayers who initially supported the research. 
Universities play a crucial role in the development of entrepreneurial culture by intensifying the inclusion of educational activities (programs, teaching/learning methods) related to the development of entrepreneurial competencies and initiatives in all educational institutions, especially higher education.

2. Support and implementation of the startups' idea largely depend on cooperation between technology startups and big corporations. Such cooperation can be crucial to stimulate the initiative of new startups and provide support for corporate innovation. Mutual understanding of the risks and problems faced by each party allows not only to minimize their impact but also to provide mutual support in the most critical areas of operation (figure 4).

Figure 4: Effectiveness of interaction between startups and corporations

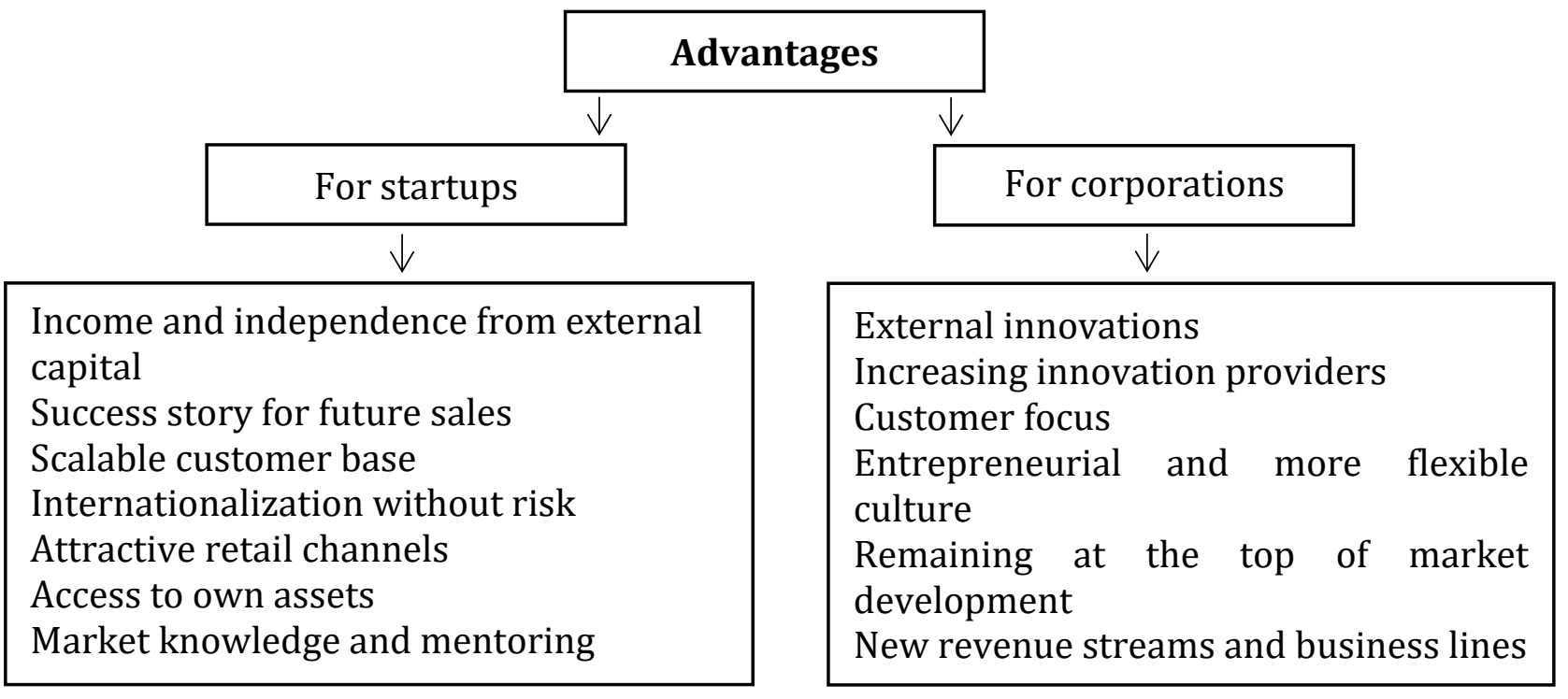

Source: Authors.

Cooperation between corporations and startups is a challenge for both partis. Corporate employees seek to follow standardized processes and, at the same time, challenge the creative behavior of entrepreneurs. Many entrepreneurs are starting their companies with the intention of disrupting corporations' status quo and challenging the players whose monopoly they seek to break.

3. The regional clusters' development promoting. Formed in some regions (cities), innovation and financial infrastructure are becoming an influential factor in the development of startups. There is even competition between individual regions for the formation of regional business ecosystems. Infrastructure, culture, i.e., the ecosystem as a whole, is crucial for the movement of enterprising people in such regions. According to international experience, the startups' ecosystem is being launched in some regions, which eventually becomes an example in the country. Leading startup hubs such as Silicon Valley, London, and New York continue to dominate at the highest level and maintain toplevel status for most subsectors. Cities support a culture of creativity and innovation that allows new companies to be born and thrive and to create more significant opportunities 
for people to grow and develop. In fact, in the world, there is a competition between different cities, districts of the city, many cooperative spaces, accelerators, and incubators for the conditions of starting a business, the development of startup culture. In foreign science, even a new scientific direction is being formed - the science of startup ecosystem assessment.

4. Business ecosystem formation. The startup movement has a very complex nature, which cannot be initiated by purely formal conditions. That is why we are talking about the formation of the ecosystem as a whole. The World Economic Forum in 2013 defined the internal components of the ecosystem (figure 5).

Figure 5: The components of the entrepreneurship ecosvstem

The components of the entrepreneurship ecosystem

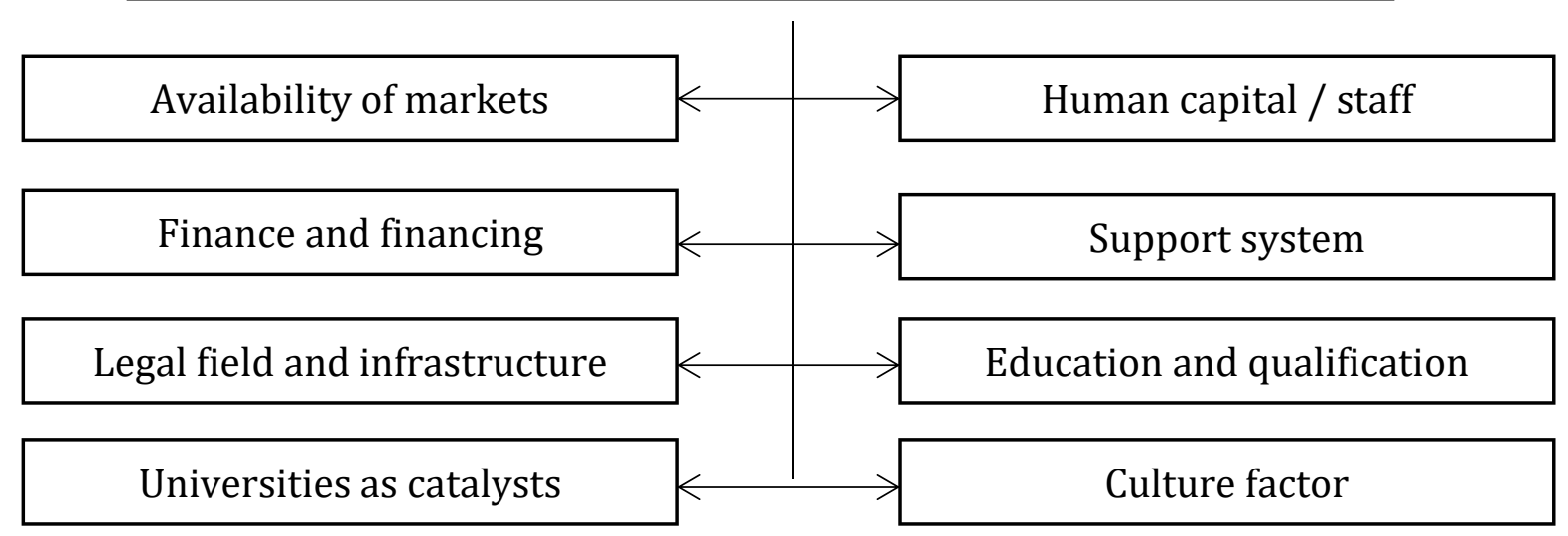

Source: World Economic Forum.

Michael Libes gives a more accurate definition of an ecosystem for startups. According to his definition, the ecosystem consists of 6 components: talent, education system, financing system, incubators and accelerators, mentoring, places, and events.

\section{Conclusion}

Startups' supporting is a complex process and to implement it you need to: increase investment by the state; to support the social orientation of innovative projects; to develop entrepreneurial culture; strengthen the intellectual property regime; develop state bills that will promote the development of innovative entrepreneurship; strengthen information opportunities for innovators to participate in international programs.

The priorities for any country are: to promote the effective functioning of startups; to create mechanisms to increase the effectiveness of their activities; to recognize the importance of innovative technologies for the successful development of enterprises.

The activity will be beneficial if you use the following agglomeration: to create a system of guarantees and investment insurance; to maintain a state register of structures in the field of venture investment; to organize training systems for innovation managers; to 
provide guarantees of companies' intellectual property rights - some forms of intellectual property rights are essential to prevent competitors from copying products and services; to develop an effective mechanism for the formation and use of venture funds; to develop a regulatory framework for regulating legal relations in the field of investment in innovation; to develop procedures for admission to the foreign capital market; to develop a methodology for assessing market prospects within the implementation of startups.

\section{References}

1. BLANK, S., B. DORF, 2013. Startup. Founder's Handbook. M.: Alpina Publisher, 616 $\mathrm{p}$.

2. BOSMA, N., J. MEIJAARD, G. van POPTA, 2002. Learning in the business start-up process (Scientific Analysis of Entrepreneurship and SMEs) [online]. [accessed: 2020-01-10]. Available from: https://core.ac.uk/download/pdf/7074583.pdf

3. CHEAH, S., Y.P. HO, P. LIM, 2016. Role of public science in fostering the innovation and startup ecosystem in Singapore. Asian Research Policy. 7(1), 78-93.

4. DOLFSMA, W., D. SEO, 2013. Government policy and technological innovation-a suggested typology. Technovation. 33(6-7), 173-179.

5. Europe's Hidden Entrepreneurs Entrepreneurial Employee Activity and Competitiveness in Europe, 2016. World Economic Forum [online]. [accessed: 2019-12-11].

Available

from: http://www3.weforum.org/docs/WEF_Entrepreneurship_in_Europe.pdf.

6. European Network of Startups, Startup and Scaleup Ecosystem: Recommendations for policy change [online]. [accessed: 2020-05-10]. Available from: https://startupeurope.network/

7. Global Entrepreneurship Monitor. Global Report 2017/2018 [online]. [accessed: 2020-01-12]. Available from: https://www.gemconsortium.org/report

8. Global Startup Ecosystem Report 2018 [online]. [accessed: 2020-02-28]. Available from: https://startupgenome.com/reports/2018/GSER-2018-v1.1.pdf

9. Global Startup Ecosystem Report 2019 [online]. [accessed: 2020-02-28]. Available from: https://startupgenome.com/reports/global-startup-ecosystem-report2019.

10. GRAHAM, P., 2012. Startup - Growth [online]. [accessed: 2020-01-10]. Available from: www.paulgraham.com.

11. HEYETS, V. M., 2015. Barriers to industrial development on the basis of innovation and opportunities to overcome them. Ukraine economy. 1, 14. ISSN 2522-9478.

12. HOANG, N., 2015. A Guide for startups Bachelor's Thesis [online]. [accessed: 202002-05]. Available from: https://www.theseus.fi/bitstream/handle/10024/101255/Hoang_NgaQuynh.pd f? sequence $=1$

13. IVASHOVA, N.V., 2013. Start up projects - a tool for implementing innovations. Economic problems of sustainable development: international. Science- practical 
Conf., April 24-26, Sumy, 4, 115-116 [online]. [accessed: 2020-03-20]. Available from: https://essuir.sumdu.edu.ua/bitstreamdownload/123456789/30770/1/Ivashova\%20N.V._Startup.pdf;jsessionid=E80FDA88112B14B3C4F939A3C424D826

14. KASHIRIN, A.I., A. S. SEMENOV, 2008. In search of a business angel. Russian experience in attracting start-up investments. M.: Peak, 384 p. ISBN 978-5-96260354-4.

15. KASYCH, A., A. DZHURA, 2019. Startups as a form of entrepreneurial activity: concept, meaning, foreign experience. Investments: practice and experience. 2, 2431.

16. KUMAR, G.P., 2018. Indian startups - issues, Challenges and opportunities. Conference: Indian Startup Ecosystem - Challenges and Opportunities, At Hyderabad [online]. [accessed: 2020-03-05]. Available from: https://www.researchgate.net/publication/323855305_INDIAN_STARTUPS_ISSUES_CHALLENGES_AND_OPPORTUNITIES/citation/download

17. LALU, F., 2017. Companies of the future. H.: KSD, 544 p. ISBN 978-617-12-2469-8.

18. MANSFIELD, M., 2018. Startup statistics - the numbers you need to know. Small Business Trends [online]. [accessed: 2019-10-10]. Available from: https://smallbiztrends.com/2016/11/startup-statistics-small-business.html

19. MINNITI, M., 2008. The role of government policy on entrepreneurial activity: productive, unproductive, or destructive? Entrepreneurship Theory and Practice. 32(5), 779-790.

20. MITTAL, S., 2014. A survey of architectural techniques for improving cache power efficiency, Sustainable Computing: Informatics and Systems. 4(1), 33-43

21. MRYKHINA, O.B., A.R. STOYANOVSKY, T. I. MIRKUNOVA, 2015. Perspectives of startup companies in the context of competitive development of the Ukrainian market of high technologies. Actual problems of economy. 9 (171), 215-225.

22. Number of UK start-ups rises to new record, 2017. Financial Times [online]. [accessed: 2020-04-05]. Available from: https://www.ft.com.

23. OKRAH, J., N. NEPP, E. AGBOZO, 2018. Exploring the factors of startup success and growth. The Business and Management Review. 9(3), 229-237.

24. PATANAKUL, P., J.K. PINTO, 2014. Examining the roles of government policy on innovation. The Journal of High Technology Management Research. 25(2), 97-107.

25. RIS, E. 2012. Business from scratch: Lean Startup method for quick testing of ideas and choosing a business model. M.: Alpina Publisher, 253 p. ISBN 978-5-9614-66232.

26. SALAMZADEH, A., H. KESIM, 2015, Startup Companies: Life Cycle and Challenges. The 4th International Conference on Employment", Education and Entrepreneurship (EEE), At Belgrade, Serbia [online]. [accessed: 2020-01-15]. Available from: https://www.researchgate.net/publication/280007861_Startup_Companies_Life _Cycle_and_Challenges.

27. The Kauffman Index of Startup Activity [online]. [accessed: 2020-04-05]. Available from: 
https://www.kauffman.org/ /media/kauffman_org/microsites/kauffman_index /startup_activity_2016/kauffman_index_startup_activity_national_trends_2016.p df.

28. TIL, P., 2015. From zero to one. Notes on startups, or how to create the future. Obukhov. K .: Nash format, 232 p. ISBN 978-617-7279-14-2.

29. The Startup Europe Ecosystem. Analysis of the Startup Europe projects and of their beneficiaries Luxembourg: Publications Office of the European Union, 2018. 46 p. [online]. [accessed: 2020-04-05]. Available from: http://publications.jrc.ec.europa.eu/repository/bitstream/JRC110945/jrc11094 5_jrc110945_the_startup_europe_ecosystem.pd

30. VOLOSHYN, D. 2017. Management models for startups: how to find your management style [online]. [accessed: 2020-04-05]. Available from: https://roem.ru/30-09-2017/260111/style-upravleniya/

31. WATSON K., S. HOGARTH-SCOTT, 1998. Small business start-ups: success factors and support implications. International Journal of Entrepreneurial Behaviour \& Research. 4(3), 217-238.

32. World Economic Forum [online]. [accessed: 2020-04-05]. Available from: https://www.weforum.org/

33.ZILGALVIS, P., 2014. The need for an innovation principle in regulatory impact assessment: The case of finance and innovation in Europe. Policy \& Internet. 6(4), 377-392.

\section{Contact address of the authors:}

Alla Kasych, D. Sc. (Economics), Professor, Head of Department Management and Public Administration, Kyiv National University of Technologies and Design, 2 NemyrovychDanchenko Street, 01011, Kyiv, Ukraine, e-mail: kasich.alla@gmail.com

Aliaksandr Amelyaniuk, Associate Professor, Department of Theory of Economics and Logistics, Brest State Technical University, Moskovskaya Street 267, 224017 Brest, Belarus, e-mail: et@bstu.by 